\title{
Multi-Criteria Group Decision Making Development: A Model Development Based on Turkish Government Agency's Strategic Planning Template
}

\author{
Emin Başar Baylan ${ }^{1, *}$, Yasemin Claire Erensal ${ }^{2}$ \\ ${ }^{1}$ Faculty of Engineering, İstanbul Commerce University, Turkey \\ ${ }^{2}$ Faculty of Engineering, Marmara University, Turkey
}

Received October 6, 2019; Revised November 15, 2019; Accepted November 22, 2019

Copyright $\subseteq 2020$ by authors, all rights reserved. Authors agree that this article remains permanently open access under the terms of the Creative Commons Attribution License 4.0 International License

\begin{abstract}
Strategy prioritizing in strategic plans requires evaluating large amount of information and data. Technically, this process is carried out by a heterogeneous planning team within an organization who are generally working in different departments and management levels. This situation creates a significant problem in group decision making and in its process since each and every group members may think their departments' benefits when making a decision rather than overall organization's goals and targets. To overcome this situation, this study looks for an alternative way for the group decision making which can enable groups to follow an objective path to overcome subjective views and decisions. Accordingly, the aim of this study is to develop a group decision making model based on the strategic planning template. Strategic planning template chosen for this study belongs one of the Turkish Government Agency operating in mining industry. Developed model was build based on the ANP-VIKOR hybrid method. Findings showed that the new developed model facilitates shorter decision making time, enables to get more benefit out of the group and allows analyzing large amount of rationality for the government agency.
\end{abstract}

Keywords MCDM, Strategic Planning, ANP, VIKOR, SWOT Analysis

\section{Introduction}

Strategy is the determination of the basic long term goals of an enterprise, and the adoption of courses of actions and the allocation of resources necessary to carry out these goals Chandler [6]. Based on this, strategic planning can be defined as the process of determining business, corporate strategies and performance measures on the bases of internal-external environment analysis by developing mission to reach the vision. In the management literature, strategic planning gained more popularity especially after the companies getting larger, more competitive and industries getting more complex and competitive Kelly [10]. Strategic planning involves continuously reviewing the internal and external environment and then making long term and short term decisions to ensure survival company. Indeed, strategic planning is the first and most important step in strategic management that can be affected from some sort of uncertainties. This general plan contains and motivates other types of departmental plans such as human resource planning, financial planning, production planning and marketing planning etc. It is because; strategic plan is the top management level plan which must be obeyed by the other functional management plans Raynor [13]. However, preparing and implementing a strategic plan is a hard job and requires a number of issues to be considered. Technically, successful strategic planning process can only be maintained by carrying out an effective research and analysis, ability to think strategically and consensus within a strategic planning team. Nevertheless, effective strategic decisions require more conditions. For example, objectivity is very important and thus strategy has to be determined according to interest of all departments not for the favour of any particular group and department Shenkar \& Luo [15]. Similarly, effective analysis skills are also important since wrong analysis may lead to wrong decisions which in return may cause significant financial, people, commercial, quality, productivity losses and business failures. Likewise, to reach specific targets, strategic planning team develops different strategic alternatives. Different strategies mean different way to reach targets which have different cost, risk and benefit. Strategy selection among these different alternatives is very hard and controversial task especially when the strategic plan requires large amounts of data, analyses Drejer[8]. Despite the fact that there exists a number of 
strategic decisions making tools which can help groups to achieve strategic decisions such as SWOT analysis, PESTEL analysis, critical success factor analysis, cultural web analysis, process mapping, causes effect analysis, problem definition sheets and brainstorming, many of these tools has a lack of ability in prioritizing strategies because of their non-analytic nature, thus, cannot provide ultimate solution for the group decision making. Besides that, many of these tools were not created based on a particular industry and were not customized for the governmental organizations' cultures and structures. Carlsen \& Andersson [5]. Therefore, the aim of this study is set as to design a model for prioritizing strategies of a strategic planning template of a chosen governmental organization. For doing this, Strategic Planning Template of Turkish Government Agency is used as template. This template is prepared by the Turkish government and used in all government's organizations. Therefore, the model which will be proposed in this study will be able to be used by the all Turkish government's organizations. In this context, this study offers several contributions and originality. First of all, most of the strategy prioritization research and studies are conducted in developed countries. Thus, by conducting this study in Turkey, this research will help filling the gap exists in the literature. Secondly, most of the strategy related studies (i.e. strategic planning, strategy prioritization etc.) mostly done in the context of private organizations. However, this study is based on the public organization which gives a new insight in understanding the importance of strategic planning and prioritization of the strategies. In addition, the model which will be provided in this study can be used in other public organizations in Turkey as well as in other developing countries. This can improve the productivity of the public organizations and thus overall economy of the developing countries.

As defined by Robinson [14] strategic planning involves all necessary management disciplines including planning, organizing, and control. Expressed in another way, strategic planning is the course of action that necessitates the definition and implementation of a company's mission by means of synchronizing the capabilities of the company with the demands of the environment Dessler[7]. It is possible to delineate the features of strategic planning as looking out, looking in and looking ahead. Looking out can be described as discovering the external setting of a company in order to determine realizable goals and identify major skills in the company while looking in stands for the evaluation of the internal setting of the company such as the management team which is the key aim, economics, and further fundamental resources to support the given current assets Bonn [3]. Then again, looking ahead can be described as merging the strategy, structures and assets of a company for the purpose of achieving set objectives. This also includes the need for scrutinizing and fine-tuning the process in times of necessity Brinkerhoff [4]. Below, the factors of strategic planning are explained briefly Dessler
[7]:

- Mission statement: Mission statement is sentence that defines the existence of foundation. It mentions the profession of foundation and which customer entities it is serving to.

- Vision statement: Vision statement is general purpose that defines the position which the foundation desired to be.

- Fundamental values of foundation: these are listed statements which imply characteristic properties of foundation.

- SWOT analysis: SWOT table is constructed to represent current situation of foundation in terms of strengths, weaknesses opportunities, treats. This analysis is conducted after PESTLE, internal and external analysis Kaplan \& Norton [9].

- Strategic goals: Strategic goals are breakdown structure form of foundation's vision. These are some long term objectives that may be assumed as milestones for reaching the vision.

- Strategic targets: Strategic targets are settled as breakdown structure form of strategic goals. They have to written in SMART (specific, measurable, assignable, realistic, time related) form Pinto [12].

- Performance targets: Performance targets are settled for controlling achievement ratio of strategic targets. They are generally related with input, output, productivity and quality terms.

- Strategies: Strategies are alternative ways being developed to reach strategic targets. There may be several strategy alternatives for one particular strategic target Barney \& Clark [1].

Despite it is significantly used by the organizations, SWOT Analysis which is a process ideally used alongside many other models and processes to assess an organization and determine the most important issue to focus on has number of weaknesses when it is used by the groups in decision makings. In principle, it is possible to define this problem as an unstructured decision problem. It is a difficult task to categorize these types of problems since they encompass a great deal of vagueness, a number of variables and limitations. The fundamental directive of this problem is prioritizing the options provided by the SWOT elements. In fact, SWOT elements involve various stochastic factors and the majority of which are uncontrollable and act erratically. Therefore, it is not possible to estimate the practicability, costs and time needed for the execution of those elements precisely. In addition, the decisions, mainly the group decisions, are based on human reasoning. No matter if the given humans are professionals, the features of human reasoning involves subjectivity and vagueness. Usually, it is also hard to attain a right consensus. Likewise, human brain is capable of dealing data in small quantities in one time and thus it is rather hard to take healthy group decisions. This calls for the combination of all professionals' views and handling 
the decision problem by taking into account all the factors given above. It is important to do this since taking the correct decision regarding the choice of strategy, particularly in the management levels, contributes a considerable degree of added-value to the company. This causes the strategy ranking problem to be considered as very important since the accomplishing the companies' objectives depend on the choosing right strategies.

Explanations made in the previous paragraphs confirm the significance of strategy ranking and selection problem. Therefore, mathematical methods should be used in prioritising the strategies. In this way starting from the early 2000s, scholars have commenced to model this decision in a mathematical manner. Initially, they implemented a multi-criteria decision making technique in order to formulate the SWOT elements. First these methods was emerged in 2001, Kangas and others combined SWOT analysis and AHP to prioritize sub-SWOT factors, then evaluate strategies according to prioritized SWOT information. Finish Forest Certification case is analysed by that method (Kangas and others, 2001). In 2003, multi-criteria based strategy selection method is used to compare tourism strategies of two different towns Kajanus \& others [17]. Combination of SWOT and AHP methods applied to strategic plan of a medical service to increase their portfolio of clients (Osuna and Aranda [18]. In 2007 Turkish researchers analyzed Turkish textile industry and make strategy suggestions with using SWOTANP hybrid method. They prioritize strategy alternatives of a textile firm by using ANP part of this method Yüksel $\&$ Dağdeviren[19]. TOPSIS method was used with SWOT analysis to prioritize strategies Ghorbani and others [20]. After these studies, some researchers propose a number of different calculating techniques for SWOT elements which are sorts of group decision techniques for assessments of pairs. Moreover, they recommend that their technique is modelled through the addition of stochastic and fuzzy characteristics which may increase the sensitivity of judgment. However, all of the motioned developments were not enough to provide a better strategic decision making model. Limitations are shown below:

- In case a strategy selection problem is considered, following a complete SWOT analysis, a scenario analysis should also be performed. The reason intended for this is that strategic plans are long-standing plans addressing the future. Therefore, developed projects intend for external environment's state of affairs in the future. It is the responsibility of strategy professionals to devise strategies for future circumstances through the employment of estimation methods and workshop methods. They contribute the information they gather through this onto the results of the SWOT analysis when they are assessing the strategy options. Nevertheless, the analytic strategy selection methods in the literature do not involve any scenario analysis. The sole analysis criteria for them are the SWOT analysis results. It is a fact that modelling scenario analysis in an analytical way is a difficult task. However, taking scenario analysis into account also enhances the soundness of the model. The mere research which takes scenario analysis into account when modelling the strategy selection problem is that of Leskinen \& others [11]. Nonetheless, the work of Leskinen \& others [11] could not succeed in generating sufficient effect on other scholars towards enhancing the studies in this direction.

- All strategy selection hybrid techniques available in the literature have two levels, which are SWOT analysis and alternative strategies. Each strategic technique is formed to arrange strategies of a strategic plan according to the importance degrees. In fact, prioritization of strategies in a strategic plan is a more difficult and problematical issue.

- In the strategic planning methodology, strategy concept is divided into three levels, which are strategic goals, strategic targets and strategies. Moreover, each technique used for prioritization or selection of strategy is formed in order to assess a considerable deal of strategic information. Contemplating from this point of view, it can be suggested that present analytic strategy selection or prioritization methods are insufficient in terms of coverage.

- Theoretically, it is a difficult task to perform pair-wise comparison for assessing the SWOT factors, secondary factors and alternative strategies. While a number of scholars propose a number of alternative data comparison methods they are not efficient in providing the results.

As a consequence of these results, this study concentrates on establishing a multi-criteria decision making technique incorporated with strategic goals, strategic targets and strategies prioritization technique for the course of strategic planning.

\section{Materials and Methods}

Since the task at hand is to model a strategy ranking component of a strategic plan, a strategic planning template needs to be employed. Strategic planning templates are outlines which are used for devising plans based on a pattern. The template used in this research is called as the Strategic Plan Guide of Government Agencies that is summarized in Table 1. provided by the Turkish Government. In Turkey, every governmental agency needs to devise strategic plans according to the Government Financial Audit and Control Law (Law no. 5018). This strategic plan comprise of the objectives of the governmental agency in the medium and long term, fundamental principles and policies, objectives and priorities, performance measures, strategies that should be performed to accomplish them. 
Table 1. Strategic Planning Template

\begin{tabular}{|c|c|c|}
\hline $\begin{array}{l}\text { PLANS AND PROGRAMS STAKEHOLDER ANALYSIS } \\
\text { SWOT ANALYSIS }\end{array}$ & $\begin{array}{l}\text { CURRENT } \\
\text { ANALYSIS }\end{array}$ & WHERE ARE WE? \\
\hline $\begin{array}{l}\text { EXISTENCE REASON OF FOUNDATION } \\
\text { FUNDAMENTAL PRINCIPLES }\end{array}$ & MISION AND PRINCIPLES & \multirow{3}{*}{$\begin{array}{l}\text { WHERE DO WE WANT TO } \\
\text { REACH? }\end{array}$} \\
\hline THE FUTURE DESIRE & VISION & \\
\hline $\begin{array}{l}\text { GOALS THAT ARE TO BE REACHED IN THE MIDDLE } \\
\text { TERM }\end{array}$ & $\begin{array}{l}\text { STRATEGIC GOALS AND } \\
\text { STRATEGIC TARGETS }\end{array}$ & \\
\hline $\begin{array}{llllll}\text { METHODS } & \text { FOR ACHIEVING } & \text { THE } & \text { GOALS } & \text { AND } \\
\text { TARGETS } & & & & & \\
\end{array}$ & STRATEGIES & \multirow{2}{*}{$\begin{array}{l}\text { HOW CAN WE ACHIEVE OUR } \\
\text { GOALS AND TARGETS? }\end{array}$} \\
\hline $\begin{array}{lccc}\text { DETAILED } & \text { BUSINESS } & \text { PLANS } & \text { COSTING } \\
\text { PERFORMANCE PROGRAM BUDGETING } & \\
\end{array}$ & $\begin{array}{l}\text { PROJECTS } \\
\text { ACTIVITIES }\end{array}$ & \\
\hline REPORTING BENCHMARKING & MONITORING & \multirow[b]{2}{*}{$\begin{array}{l}\text { HOW DO WE EVALUATE OUR } \\
\text { SUCCESS? }\end{array}$} \\
\hline $\begin{array}{l}\text { FEEDBACKS DETERMINATION OF MEASUREMENT } \\
\text { METHODS PERFORMANCE INDICATORS } \\
\text { EVALUATION RESULTS OF PROGRESS }\end{array}$ & $\begin{array}{l}\text { PERFORMANCE } \\
\text { MEASUREMENT } \\
\text { EVALUATION }\end{array}$ & \\
\hline
\end{tabular}

\subsection{ANP-VIKOR Hybrid Strategy Prioritization Method}

In a strategic planning course, a fundamental task is to choose the strategy to prioritize. In principle, the entire process of planning is performed in order to choose the correct strategies. Typically, it is the job of the strategic planning team to deal with the selection of the strategy through a number of workshop methods such as brainstorming, Delphi method, cause-and-effect schemas or assessment matrices. The mentioned techniques fall short in performing perfectly in a short interval, with the involvement of the entire team and in an objective manner. In the current research, a multi-criteria decision support technique is generated for making a healthy group decision and negotiation course available.

In principle, this model comprises of the incorporation of ANP and VIKOR techniques to strategic planning information. Figure 1 Baylan \& Erensal[2] illustrates strategic decision hierarchy of strategic planning template. It also gives idea how ANP-VIKOR technique can be used in government agencies' strategic planning: 


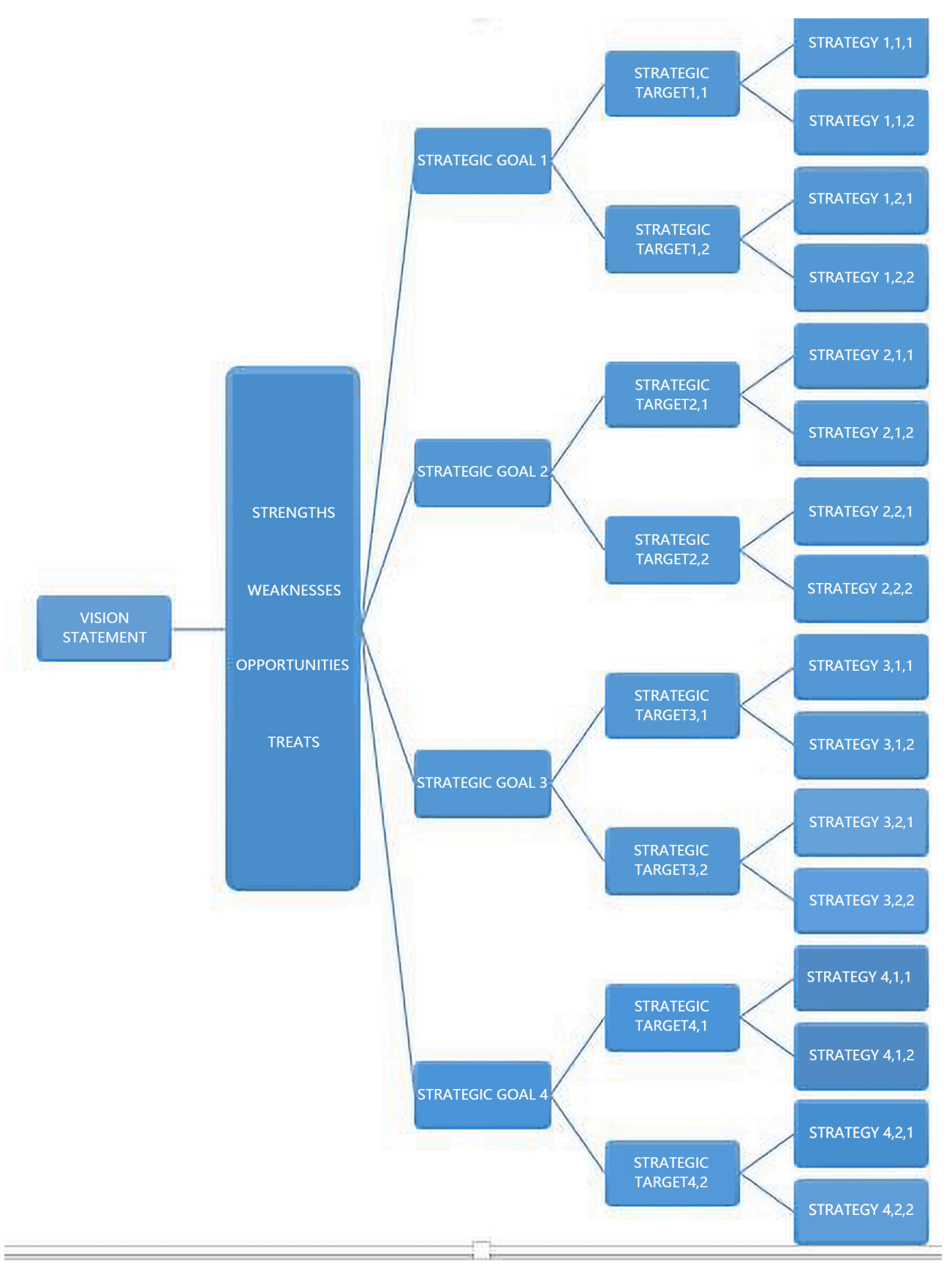

Figure 1. Strategic Decision Hierarchy of Government Agency Strategic Plan 


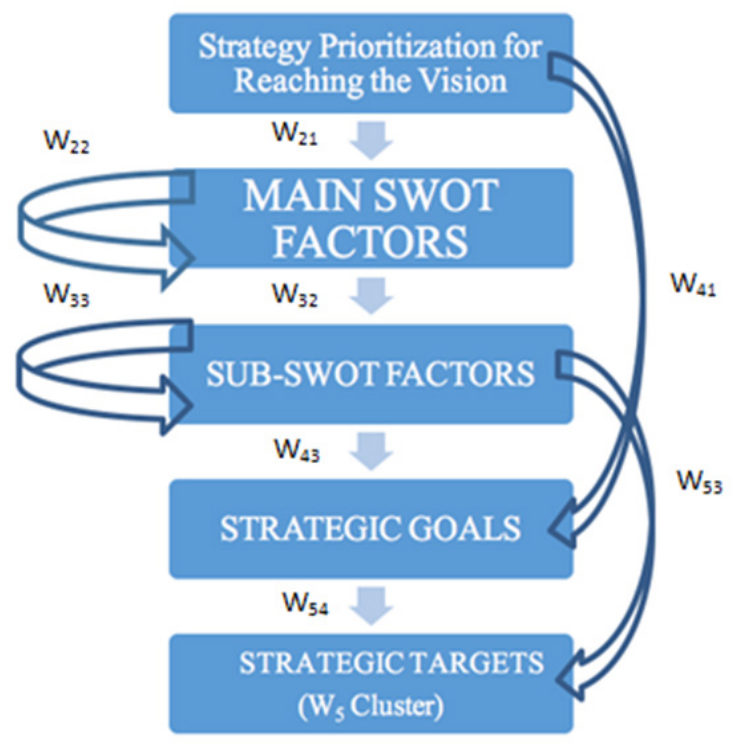

Figure 2. Analytic Network Model of Strategic Target Prioritisation Process

ANP-VIKOR hybrid strategy prioritization technique consists of two levels. In the first level of the technique, ANP method is used for prioritizing strategic targets. A systematic network which combines vision statement, fundamental SWOT elements, secondary SWOT elements, strategic goals and strategic targets is developed for the construction of the first part. Figure 2 Baylan \& Erensal[2] which is the Analytic Network Model of Strategic Target Prioritization Process presents how this information can be used in the construction of the first part of the model.

The ultimate objective of this part is to understand the strategic targets of the company and prioritize these targets in order to their importance. In doing this, first of all, strategic objectives which are determined based on the SWOT factors should be compared pairwise. Following to this, sub-SWOT factors should be compared pairwise in order to further prioritize the strategies. Pairwise comparison questions of this network model are listed in Appendix. For example pairwise comparisons table for strategic goals with respect to vision statement is as below;

As an example of model, strategic goal statements of General Directorate of Mineral Research and Exploration's (2015-2019) strategic plan

STRATEGIC GOAL 1: Producing information on land and on the seas in the field of geology according to our country's requirements and ensuring that the earth's crust is understood and utilized efficiently.

STRATEGIC GOAL 2: Conducting exploration and research activities in accordance with the national and international production, consumption, import, export criteria and critical raw material predictions on minerals and energy raw materials and contributing to the assurance of reserve reliability in our country.

STRATEGIC GOAL 3: Conducting technological studies in accordance with our country's requirements, developing, diversifying and expediting analysis/testing services; in the field of geology and mining.

STRATEGIC GOAL 4: Researching and promoting the history of nature and contributing to the efforts for protecting geological heritage.

STRATEGIC GOAL 5: Developing and strengthening the corporate structure

Pairwise comparison questions of ANP part of decision model represented in Appendix Table 13. As an example, pairwise comparisons table for strategic goals with respect to vision statement is as below;

Table 2. Pairwise comparison table for strategic goals with respect to vision statement

\begin{tabular}{|c|c|c|c|c|c|}
\hline $\begin{array}{c}\mathrm{W}_{21} \\
(f=1,2,3,,, s)\end{array}$ & Strategic Goal 1 & Strategic Goal 2 & Strategic Goal 3 & Strategic Goal 4 & Strategic Goal 5 \\
\hline Strategic Goal 1 & 1 & 4 & 5 & 2 \\
\hline Strategic Goal 2 & $1 / 4$ & 1 & 3 & 2 \\
\hline Strategic Goal 3 & $1 / 5$ & $1 / 3$ & $1 / 4$ & 4 & 1 \\
\hline Strategic Goal 4 & $1 / 6$ & $1 / 2$ & $1 / 5$ & $1 / 3$ \\
\hline Strategic Goal 5 & $1 / 2$ & 1 & 1 & 5 \\
\hline
\end{tabular}


After construction of pairwise comparison matrices, consistency ratio is to be calculated. Consistency ratio measures how much consistent the experts scaled pairwise comparison matrices. To calculate consistency ration two formula needed as below;

$$
\begin{aligned}
& C . I=\frac{(\lambda \max -n)}{n-1} \\
& C . R .=\frac{C . I}{R . I}
\end{aligned}
$$

\section{C.I.: Consistency index}

$\lambda \max$ : Eigen value of pairwise comparison matrix $n$ : Number of elements in pairwise comparison matrix

R.I.: Random consistency index. R.I. is derived from Random Consistency Index as shown in Table 3.

$C . R$ : Consistency ratio of pairwise comparison matrix

These pairwise comparisons (show its scale in Table 2) are supposed to be made by strategic planning team. This evaluation process allows speed decision making, possibility of deciding without any hierarchic pressure and ability of evaluating large number of information. After pairwise comparison tables are filled eigenvectors of every table are calculated to allocate initial supermatrix of ANP model.
Following to pairwise comparison, results must be entered to Supermatrix in order to prioritize the strategies that is shown in Table 3 Baylan \& Erensal[2]. Elements of Supermatrix form of ANP model are listed as below;

V: Vision statement of foundation.

S: Strengths cluster of foundation as a general caption.

We: Weaknesses cluster of foundation as a general caption.

$\mathrm{O}$ : Opportunities cluster of foundation as a general caption.

$\mathrm{T}$ : Threats cluster of foundation as a general caption.

$\mathrm{S}_{1},,{ }_{,}, \mathrm{S}_{\mathrm{k}}$ : Each strength statement of foundation. $\mathrm{k}$ is number of strength statements.

$\mathrm{We}_{1},,,, \mathrm{We}_{\mathrm{v}}$ : Each weaknesses statement of foundation. $\mathrm{v}$ is number of weaknesses statements.

$\mathrm{O}_{1},,{ }_{,}, \mathrm{O}_{\mathrm{z}}$ : Each opportunity statement of foundation. $\mathrm{z}$ is number of opportunity statements.

$\mathrm{T}_{1},,,{ }_{,}, \mathrm{T}_{\mathrm{y}}$ : Each threat statement of foundation. $\mathrm{y}$ is number of threat statements.

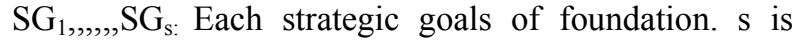
number of strategic goal statements.

$\mathrm{ST}_{1},,{ }_{,}, \mathrm{ST}_{\mathrm{g}}$ : Each strategic target of foundation. $\mathrm{g}$ is number of strategic target statements.

Table 3. Scale of Relative Importance for Pairwise Comparison Process

\begin{tabular}{|c|c|c|c|c|c|c|c|c|}
\hline $\begin{array}{c}\text { Number of } \\
\text { elements }\end{array}$ & 3 & 4 & 5 & 6 & 7 & 8 & 9 & 10 \\
\hline R.I. & 0.52 & 0.89 & 1.11 & 1.25 & 1.35 & 1.40 & 1.45 & 1.49 \\
\hline
\end{tabular}

Table 4. Supermatrix Form of ANP Model

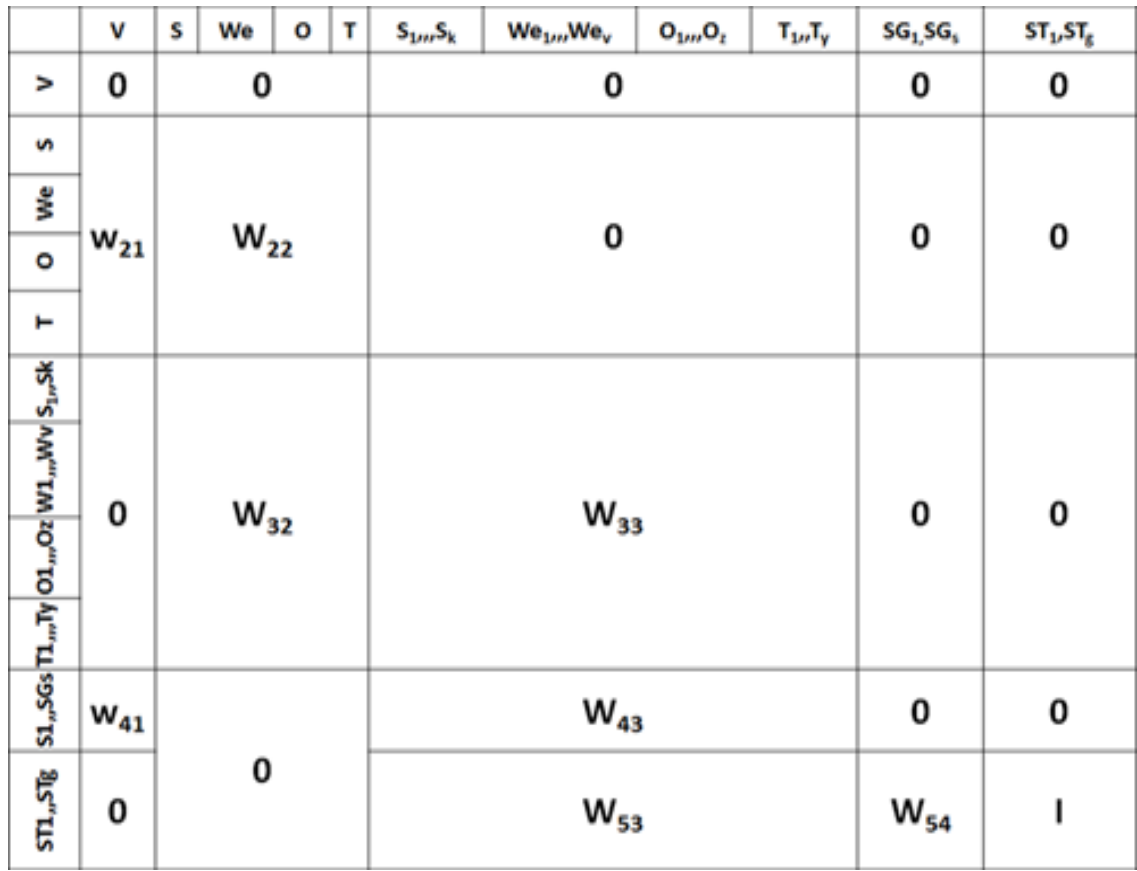


Limit matrix operations are performed to initial supermatrix of ANP model, than Limiting Global Supermatrix is obtained and shown in Table 4 Baylan \& Erensal[2]. Limitin Global Supermatrix gives same global priority vector in the same column which involves priority ratios of strategic plan elements

To continue second layer of decision model, priority values of strategic targets are (ST1, ST2,,,, STg) needed. They are normalized to distribute their weights to performance targets. To achieve this Global Priority Vector should be performed:

$$
=\left[\begin{array}{c}
\text { Global Priority Vector } \\
V S W e O T S_{1},,,, S_{k} W e_{1,}, \\
W e_{v} O_{1} O_{z} T_{1} T_{y} S G_{1} S G_{s} S T_{1} S T_{g}
\end{array}\right]
$$

Weights of strategic targets are supposed to be extracted from Global Priority Vector for normalizing. Weights of Strategic targets are derived from the above formula; WST is symbolized form of Weight of Strategic target. In strategic plan Strategic targets have their own performance targets and in second layer of decision performance target's priorities are supposed to be used. Therefore, normalized WST values are calculated at the end of first layer of decision method for finding out weights of every performance target by distributing their own priority ratio on their performance targets.

Strategic Target Weight Vector is calculated as below;

$$
\left[\begin{array}{c}
S T_{1} /\left(S T_{1}+S T_{2}+\cdots S T_{g}\right) \\
S T_{2} /\left(S T_{1}+S T_{2}+\cdots S T_{g}\right) \\
S T_{3} /\left(S T_{1}+S T_{2}+\cdots S T_{g}\right) \\
\cdots \\
S T_{g} /\left(S T_{1}+S T_{2}+\cdots S T_{g}\right)
\end{array}\right]=\left[\begin{array}{c}
W S T_{1} \\
W S T_{2} \\
W S T_{3} \\
\cdots \\
W S T_{g}
\end{array}\right]
$$

After strategic target's weight is normalized by a simple operation, Figure 3 Baylan \& Erensal[2] shows that they are distributed related performance targets. Performance target's weights are symbolized with WPTu;

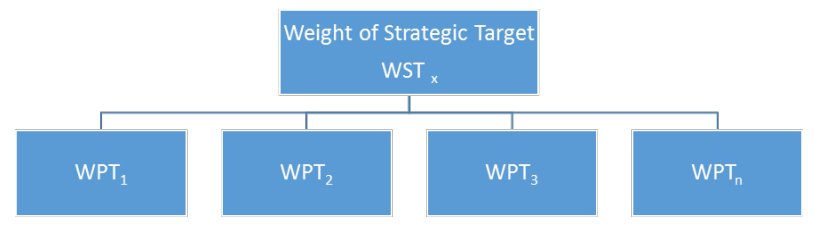

Figure 3. Strategic Target Weight and Performance Target Weight Relation

$$
\sum_{x=1}^{g} W S T_{x}=\sum_{u=1}^{n} W P T_{u}=1
$$

With the determination of performance target's weights, ANP part of ANP-VIKOR strategy prioritization method is ended. Namely, the results of ANP are used for the VIKOR model.

VIKOR part of this method aims to prioritize strategy alternatives of firms. VIKOR method is used in this model it is because negotiation of strategic planning team is an important factor. Model's inputs are described as below;

Decision Criteria: Performance indicators of strategic plan are assumed as decision criteria of VIKOR model. Their weights come from result ANP model results which is distribution of strategic target normalized prioritization values on performance targets.

Decision Alternatives: All strategy alternatives of strategic targets are assumed as decision alternatives of VIKOR model.

Decision Alternatives Impact on Decision Criteria: Technically, strategies are developed to reach performance target. But strategy alternatives are not developed clear enough to get their forecast of the impact on performance targets. Technically, strategies are developed to perform by the foundation. They are usually broken down into projects to enter into details. In this method, this hint is used. To forecast the strategy impact on performance targets, strategies are broken down into projects. Basically, strategy impact on performance targets can be measured by using following formulas:

Strategy impact on performance target $(\mathrm{SPju})=$ Performance Target (PTu) X Strategy Feasibility Ratio(STRFj) X Strategy Impact on Performance Target Ratio(STRIju)

$$
S P_{j u}=P T_{u} * S T R F_{J} * S T R I_{j u}
$$

Those ratios above defined as percentages. $S T R F_{j u}$ percentage calculation involves project feasibility analysis. Projects total feasibilities are calculated by depending on project technical, financial, duration and resource feasibility and in doing this, following parameters can be used. Table 5 Baylan \& Erensal[2] represents Project Feasibility Coefficients which will be used find Strategy Feasibility Ratio. 
Table 5. Transposed form of Limiting Global Supermatrix for ANP Model

\begin{tabular}{|c|c|c|c|c|c|c|c|c|c|c|}
\hline & v & $S$ & We & 0 & $\mathrm{~T}$ & S1 $1,,, S k$ We $1,$, Wev & $\mathrm{O} 1,,, \mathrm{Oz}$ & $\mathrm{T} 1, \ldots, \ldots, \mathrm{Ty}$ & $\mathrm{SG1}, \ldots, \ldots, \mathrm{SGs}$ & $\mathrm{ST} 1, \ldots, \ldots, \mathrm{STg}$ \\
\hline v & \multicolumn{10}{|c|}{ Global Priority Vector } \\
\hline S & \multicolumn{10}{|c|}{ Global Priority Vector } \\
\hline We & \multicolumn{10}{|c|}{ Global Priority Vector } \\
\hline 0 & \multicolumn{10}{|c|}{ Global Priority Vector } \\
\hline $\mathrm{T}$ & \multicolumn{10}{|c|}{ Global Priority Vector } \\
\hline \multirow{2}{*}{$\mathrm{S}_{1,,,} \mathrm{~S}_{\mathrm{k}}$} & \multicolumn{10}{|c|}{ Global Priority Vector } \\
\hline & \multicolumn{10}{|c|}{ Global Priority Vector } \\
\hline \multirow{2}{*}{$\mathrm{We}_{1},$, Wev } & \multicolumn{10}{|c|}{ Global Priority Vector } \\
\hline & \multicolumn{10}{|c|}{ Global Priority Vector } \\
\hline \multirow{2}{*}{$\mathrm{O}_{1,,}, \mathrm{O}_{z}$} & \multicolumn{10}{|c|}{ Global Priority Vector } \\
\hline & \multicolumn{10}{|c|}{ Global Priority Vector } \\
\hline \multirow{2}{*}{$\mathrm{T}_{1}, \mathrm{~T}_{\mathrm{y}}$} & \multicolumn{10}{|c|}{ Global Priority Vector } \\
\hline & \multicolumn{10}{|c|}{ Global Priority Vector } \\
\hline \multirow{3}{*}{$\mathrm{SG}_{1, \mathrm{SG}_{\mathrm{s}}}$} & \multicolumn{10}{|c|}{ Global Priority Vector } \\
\hline & \multicolumn{10}{|c|}{ Global Priority Vector } \\
\hline & \multicolumn{10}{|c|}{ Global Priority Vector } \\
\hline \multirow{2}{*}{$\mathrm{ST}_{1}, \mathrm{ST}_{\mathrm{g}}$} & \multicolumn{10}{|c|}{ Global Priority Vector } \\
\hline & \multicolumn{10}{|c|}{ Global Priority Vector } \\
\hline
\end{tabular}

This table is filled in for each sub-project of particular strategy. Strategy Feasibility Ratio $\left(\mathrm{STRF}_{\mathrm{j}}\right)$ is derived from the formula below;

Importance weight of particular sub-project for strategy $=\mathrm{WPmpr}$

$$
\begin{gathered}
\mathrm{WPm} 1+\mathrm{WPm} 2+\ldots \ldots \ldots . . \mathrm{WPmpr}=1 \\
S T R F_{m}=W P_{m 1} *\left(\left(T F_{m}\right)+\left(F F_{m 1}\right)+\left(D F_{m 1}\right)+\right. \\
\left.\left(R F_{m 1}\right)\right)+W P_{m p r} *\left(\left(T F_{m p r}\right)+\left(F F_{m p r}\right)+\left(D F_{m p r}\right)+\right. \\
\left.\left(R F_{m p r}\right)\right)
\end{gathered}
$$

After those calculations $S T R F_{m}$ ratio is derived for each strategy. $\left(\mathrm{STRI}_{\mathrm{m}}\right)$ value is estimated by some project output forecasting methods. PIPT $T_{\text {mpr }}$ : Project Impact on Performance Target (When making these calculations, synergy of projects must be considered. It is because this formula is deriving for cumulative impact of projects).

$$
\begin{gathered}
S T R I_{m}=\mathrm{PIPT}_{\mathrm{m} 1}+\mathrm{PIPT}_{\mathrm{m} 2}+\ldots \ldots . .+\mathrm{PIPT}_{\mathrm{mpr}} \\
S P_{j u}=P T_{u} * S T R F_{J} * S T R I_{j u}
\end{gathered}
$$

Table 6. Project Feasibility Parameters

\begin{tabular}{|c|c|}
\hline Feasibility Type & Feasibility rate \\
\hline Technical Feasibility & $0 \leq \mathrm{TF} \leq 0,25$ \\
\hline Financial Feasibility & $0 \leq \mathrm{FF} \leq 0,25$ \\
\hline Duration Feasibility & $0 \leq \mathrm{DF} \leq 0,25$ \\
\hline Resource Feasibility & $0 \leq \mathrm{RF} \leq 0,25$ \\
\hline
\end{tabular}

After decision elements of VIKOR method is determined properly, initial VIKOR table which is shown in Table 6 Baylan \& Erensal[2] can be constructed to find $\left(\mathrm{SP}_{\mathrm{ju}}\right)$ the effect of strategy performance of $\mathrm{j}$ on performance target $u$. Initial VIKOR table is changed into normalized VIKOR table with some matrix calculations. VIKOR calculations steps are listed as below;

1. VIKOR method involves tabular matrix calculations. Initial step of VIKOR calculations start with constructing initial VIKOR table. Due to customizing VIKOR method to strategy selection problem in question, strategy alternatives of strategic plan are put on the rows of VIKOR table as decision alternatives, and performance targets of strategic targets are put on columns as decision criteria. Effect of each strategy on each performance target (which means how much the particular strategy increase performance indicator value related with performance target) that is symbolized with SPiu strategy performance which are found out from the formula (9) are put on the table. At the bottom of the table maximum and minimum values each column are put that shows the value of SP values of each column Appendix Table 14.

2. In second part of VIKOR calculations, SP values are changed into NSP values which mean normalized strategy performance. For a particular performance target, these values are calculated by subtracting SP values from its maximum SP value and divided by the difference of the maximum and minimum value of SP 
value in the column. It is represented in Appendix Table 15.

3. In third step of VIKOR calculations, weighted normalized VIKOR table of strategy ranking model is obtained. Weight ratios which are calculated in figure 3 and Formula 4 are multiplied with related performance target columns Appendix Table 16

4. In final part, $S, R$ and $Q$ values calculated to use in ranking process of strategies. $\mathrm{S}, \mathrm{R}$ and $\mathrm{Q}$ values calculations are represented in Appendix Table 17. Last step of VIKOR algorithm also includes controlling the accuracy of strategy priority ranking. For doing this job, there are couples of calculations. For example, if STR1 is selected the best strategy at the final step (according to Q parameter), it must fit the conditions below;

Condition 1 -Acceptable advantage: In ranking with $\mathrm{STR}_{2}$ and $\mathrm{Q}, \mathrm{STR}_{2}$ is at the second place.

$\mathrm{Q}\left(\mathrm{STR}_{2}\right)-\mathrm{Q}\left(\mathrm{STR}_{1}\right)=\mathrm{DQ}$, if this condition is satisfied.

DQ $1 /(\mathrm{m}-1) \mathrm{m}$ is number of decision alternatives in table.

Condition 2- Acceptable balance for decision making: For being an balanced and agreed solution (for $\mathrm{STR}_{1}$ ), it must be ranked at the first place on $S_{j}$ and $R_{j}$ list [22]

If one condition is not satisfied, we consider those two other conditions below;

Unless only second condition is satisfied, $\mathrm{STR}_{1}$ in the first sequence and $\mathrm{STR}_{2}$ in the second sequence are determined as best common agreed solution.

Unless first condition is satisfied, rank list at the end of step 11 is involved by best agreed solution set. Max $\mathrm{m}$ is determined by the equation below;

$$
\mathrm{Q}(\mathrm{STRm})-\mathrm{Q}(\mathrm{STR} 1)<\mathrm{DQ}
$$

After strategies are prioritised they are distributed to their related strategic target, if it fits the conditions, Q values of strategy alternatives are sequenced in an increasing order (otherwise other calculations to be made), then they are allocated to related strategies of strategic targets. Thus, most appropriate strategy combination can be selected easily.

Following to finalising the VIKOR application, Strategy Prioritisation Results of ANP-VIKOR Hybrid Method can be drawn as on Table 7 Baylan \& Erensal[2].

Table 7. Strategy Prioritization Results of ANP-VIKOR Hybrid Method

\begin{tabular}{|c|c|c|c|}
\hline $\begin{array}{l}\text { Priority Value of } \\
\text { Strategy }\end{array}$ & Related Strategy & $\begin{array}{l}\text { Related Performance } \\
\text { Target }\end{array}$ & $\begin{array}{l}\text { Related Strategic } \\
\text { Target }\end{array}$ \\
\hline $\begin{array}{l}\text { Sequence of Strategy } 1 \\
\text { Sequence of Strategy }\end{array}$ & $\begin{array}{l}\text { Strategy } 1 \\
\text { Strategy }\end{array}$ & Performance Target 1 & \multirow{2}{*}{ Strategic Target 1} \\
\hline $\begin{array}{l}\text { Sequence of Strategy } \\
\text { Sequence of Strategy }\end{array}$ & $\begin{array}{l}\text { Strategy } 3 \\
\text { Strategy } 4\end{array}$ & Performance Target ${ }_{2}$ & \\
\hline $\begin{array}{l}\text { Sequence of Strategy } \\
\text { Sequence of Strategy } 6\end{array}$ & $\begin{array}{l}\text { Strategy } \\
\text { Strategy } 6\end{array}$ & Performance Target 3 & \multirow[b]{2}{*}{ Strategic Target $\mathrm{g}$} \\
\hline $\begin{array}{l}\text { Sequence of Strategy? } \\
\text { Sequence of Strategys } \\
\text { Sequence of Strategyg } \\
\text { Sequence of Strategy }\end{array}$ & $\begin{array}{l}\text { Strategy } 7 \\
\text { Strategy8 } \\
\text { Strategy } 9 \\
\text { Strategym }\end{array}$ & Performance Target ${ }_{n}$ & \\
\hline
\end{tabular}

\section{Application of Model: Case Study Application of ANP-VIKOR Hybrid Method to General Directorate of Mineral Research and Exploration's (2015-2019) Strategic Plan}

In Turkey, there is big government foundation which is in charge of mine research and exploration which is called "General Directorate of Mineral Research and Exploration". This general directorate is hierarchically connected to "Ministry of Energy and Natural Resources" GDMRE has 12 regional directorates in the country. Mission statement of GDMRE is "Producing and deploying knowledge to contribute the nation's welfare by conducting the research, analyze and infrastructure development activities on earth sciences and mining. Table 8 Baylan \& Erensal[2] summarizes Fundamental Strategies and Strategic Areas of General Directorate of Mineral Research and Exploration (GDMRE)[21] .

Table 8. Fundamental Strategies and Strategic Areas of General Directorate of Mineral Research and Exploration (GDMRE)[21]

\begin{tabular}{|c|c|c|}
\hline $\begin{array}{c}\text { Fundamental Strategic } \\
\text { Areas }\end{array}$ & Fundamental Strategic Goals & \\
\hline Earth Sciences Research & $\begin{array}{l}\text { Producing information on land and on the seas in the field of } \\
\text { geology according to our country's requirements and ensuring } \\
\text { that the earth's crust is understood and utilized efficiently }\end{array}$ & \multirow{4}{*}{ 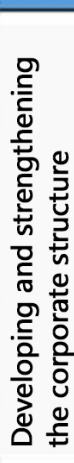 } \\
\hline $\begin{array}{l}\text { Mineral and Energy Raw } \\
\text { Material Search and } \\
\text { Research }\end{array}$ & $\begin{array}{l}\text { Conducting exploration and research activities in accordance } \\
\text { with the national and international production,consumption, } \\
\text { import,export criteria and critical raw material predictions on } \\
\text { minerals and energy raw materials and contributing to the } \\
\text { assurance of reserve reliability in our country }\end{array}$ & \\
\hline $\begin{array}{l}\text { Analysis and Technological } \\
\text { Investigations }\end{array}$ & $\begin{array}{l}\text { Conducting technological studies in accordance with our } \\
\text { country's requirements, developing,diversifying and expediting } \\
\text { analysis/testing services;in the field of geology and mining }\end{array}$ & \\
\hline $\begin{array}{l}\text { Nature History and } \\
\text { Geological Heritage }\end{array}$ & $\begin{array}{l}\text { Researching and promoting the history of nature and } \\
\text { contributing to the efforts for protecting geological heritage }\end{array}$ & \\
\hline
\end{tabular}


For making expert judgments, mining engineer and geological engineer academicians are employed. General Directorate of Mineral Research and Exploration's (2015-2019) strategic plan [21] has;

- 1 vision statement

- 13 strengths

- 9 opportunities

- 15 weaknesses
- 8 treats

- 5 strategic goals

- 21 strategic targets

That information is evaluated by ANP method and strategic targets prioritization model is solved by superdecisions software and network representation of mode is illustrated on Figure 4 Baylan \& Erensal [2]

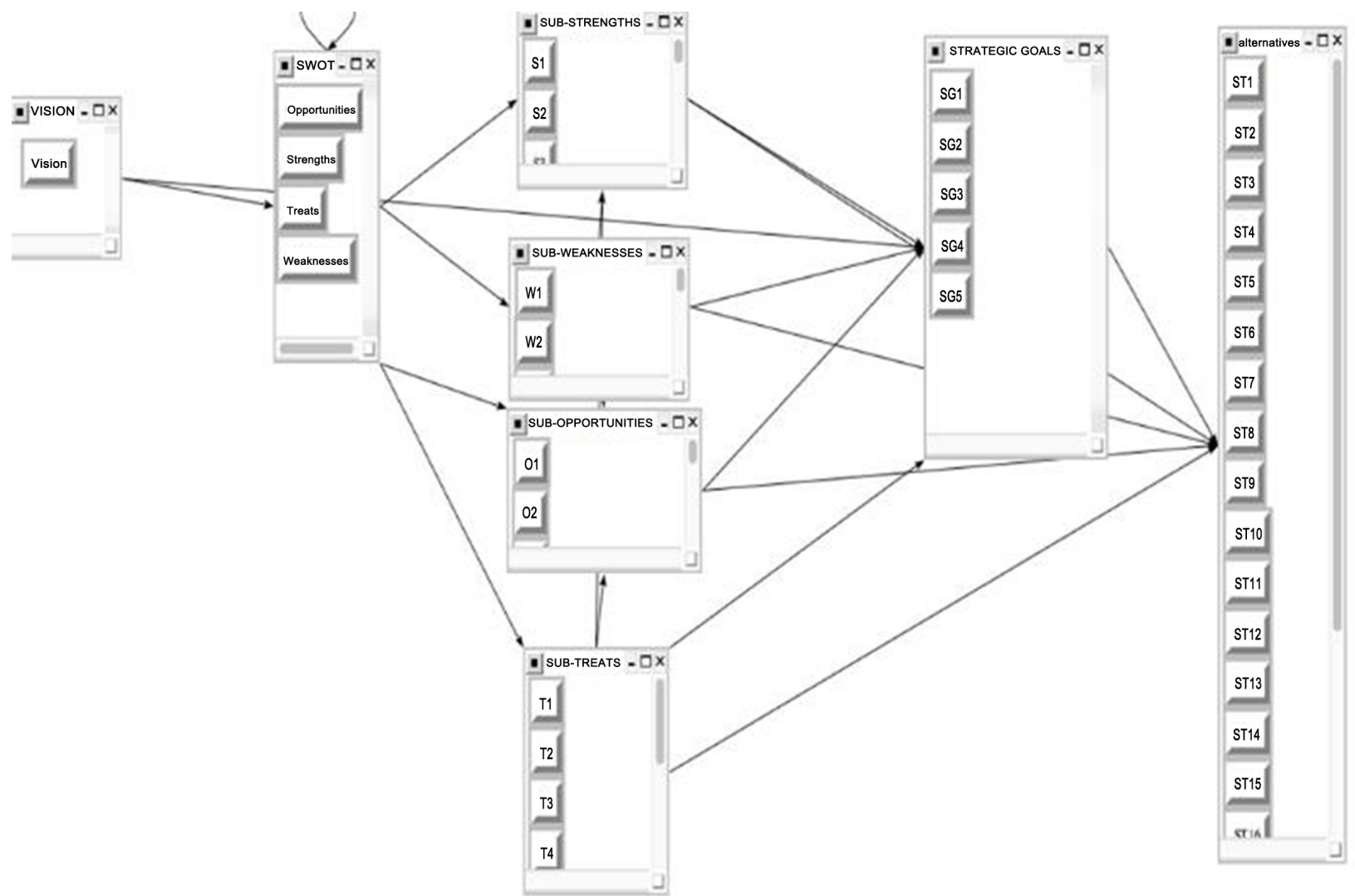

Figure 4. Superdecision Network of Strategic Target Prioritisation Model

Table 9. Table of prioritized strategic targets

\begin{tabular}{|c|c|c|c|c|c|}
\hline Graphic & Alternatives & Total & Normal & Ideal & Ranking \\
\hline 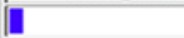 & ST1 & 0.0521 & 0.1043 & 1.0000 & 1 \\
\hline & ST2 & 0.0288 & 0.0577 & 0.5534 & 5 \\
\hline & ST3 & 0.0180 & 0.0360 & 0.3451 & 16 \\
\hline & ST4 & 0.0201 & 0.0402 & 0.3853 & 15 \\
\hline & STS & 0.0226 & 0.0452 & 0.4330 & 13 \\
\hline & ST6 & 0.0238 & 0.0477 & 0.4571 & 11 \\
\hline & S17 & 0.0319 & 0.0639 & 0.6124 & 4 \\
\hline & ST8 & 0.0280 & 0.0561 & 0.5379 & 6 \\
\hline a & ST9 & 0.0353 & 0.0707 & 0.6771 & 3 \\
\hline & ST 10 & 0.0255 & 0.0511 & 0.4895 & 8 \\
\hline & ST11 & 0.0250 & 0.0501 & 0.4804 & 9 \\
\hline & ST12 & 0.0262 & 0.0524 & 0.5021 & 7 \\
\hline 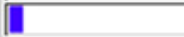 & ST 13 & 0.0357 & 0.0714 & 0.6841 & 2 \\
\hline & ST 14 & 0.0111 & 0.0222 & 0.2129 & 19 \\
\hline & ST15 & 0.0203 & 0.0407 & 0.3900 & 14 \\
\hline & ST 16 & 0.0226 & 0.0453 & 0.4338 & 12 \\
\hline & ST 17 & 0.0100 & 0.0201 & 0.1925 & 21 \\
\hline & ST 18 & 0.0139 & 0.0279 & 0.2671 & 17 \\
\hline & ST19 & 0.0249 & 0.0499 & 0.4785 & 10 \\
\hline & ST20 & 0.0127 & 0.0253 & 0.2428 & 18 \\
\hline & ST21 & 0.0109 & 0.0218 & 0.2088 & 20 \\
\hline
\end{tabular}


After strategic targets are prioritised by ANP method, their normalised values are distributed on their related performance targets. Table 10 Baylan \& Erensal[2] represents the prioritized strategic targets. Example of Strategic target weight distribution on related performance targets represented on Table 11 Baylan \& Erensal[2]

In Turkey, strategic planning plans which are open public version do not involve all strategy alternatives. They only involve only selected strategy alternatives for particular strategic targets. Because of this circumstance, in this study, 61 new strategies are developed for strategic targets by experts. There are 21 strategic targets in the original plan. Almost three strategies are assigned on each strategic target. Each strategy is broken down into projects and their feasibilities are forecasted. Sub-projects of strategies and their feasibility ratios are shown in Table 11 Baylan \& Erensal[2].

Table 10. Example of Strategic target weight distribution on related performance targets[21]

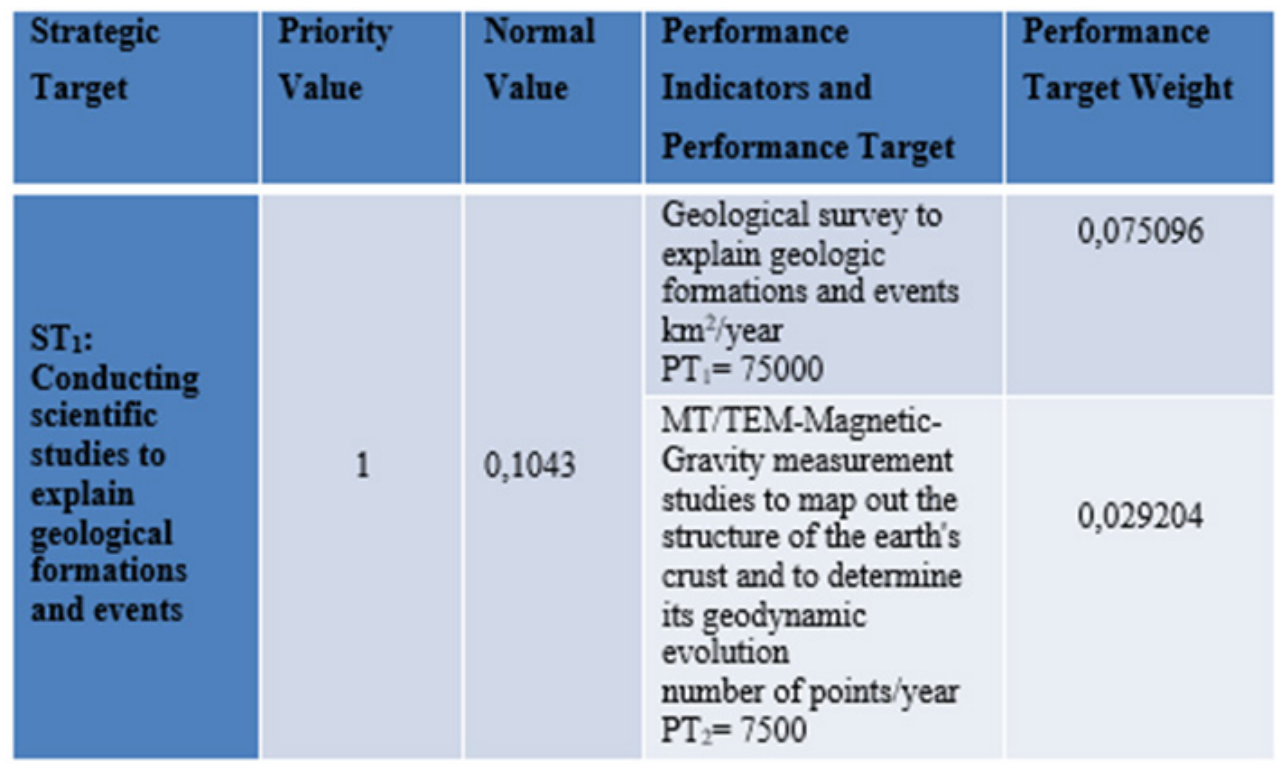

Table 11. Strategy Projects and Feasibility Ratios Example

\begin{tabular}{|c|c|c|}
\hline Projects of Strategy 1 & Project Weight & $\begin{array}{l}\text { Project Feasibility } \\
\text { Rate }\end{array}$ \\
\hline \multirow{4}{*}{$\begin{array}{l}\text { Establishing physical and information system } \\
\text { infrastructure in the foundation for } \\
\text { performing strategy } 1 .\end{array}$} & \multirow{4}{*}{0,2} & $\mathrm{TF}=0,2$ \\
\hline & & $\mathrm{FF}=0,18$ \\
\hline & & $\mathrm{DF}=0,22$ \\
\hline & & $\mathrm{RF}=0,25$ \\
\hline \multirow{4}{*}{$\begin{array}{l}\text { Selecting and training of personal whose job } \\
\text { is supporting scientific research center. }\end{array}$} & \multirow{4}{*}{0,3} & $\mathrm{TF}=0,2$ \\
\hline & & $\mathrm{FF}=0,22$ \\
\hline & & $\mathrm{DF}=0,22$ \\
\hline & & $\mathrm{RF}=0,22$ \\
\hline \multirow{4}{*}{$\begin{array}{l}\text { Determining popular scientific mining } \\
\text { subjects and employing successful scientists } \\
\text { who are studying at those subjects. }\end{array}$} & \multirow{4}{*}{0,1} & $\mathrm{TF}=0,13$ \\
\hline & & $\mathrm{FF}=0,13$ \\
\hline & & $\mathrm{DF}=0,2$ \\
\hline & & $\mathrm{RF}=0,25$ \\
\hline \multirow{4}{*}{$\begin{array}{l}\text { Establishing and implementing financial } \\
\text { support system (assigning a particular } \\
\text { research budget) to research projects. }\end{array}$} & \multirow{4}{*}{0,4} & $\mathrm{TF}=0,23$ \\
\hline & & $\mathrm{FF}=0,14$ \\
\hline & & $\mathrm{DF}=0,25$ \\
\hline & & $\mathrm{RF}=0,25$ \\
\hline
\end{tabular}


Table 12. Prioritized strategies with respect to their Q values Baylan \& Erensal[2]

\begin{tabular}{|c|c|c|c|c|c|}
\hline Strategic Target & Strategy & $\begin{array}{l}\text { Priority } \\
\text { Value of } \\
\text { Strategy }\end{array}$ & $\begin{array}{c}\mathrm{Q} \\
\text { value }\end{array}$ & $\begin{array}{c}\mathrm{S} \\
\text { value }\end{array}$ & $\begin{array}{c}\mathrm{R} \\
\text { value }\end{array}$ \\
\hline \multirow{3}{*}{$\begin{array}{l}\mathrm{ST}_{1} \text { : Conducting scientific } \\
\text { studies to explain } \\
\text { geological formations and } \\
\text { events }\end{array}$} & $\begin{array}{l}\text { STR }_{1}: \text { Within the MTA, to establish a scientific research center } \\
\text { where researchers who can make professional academic level of } \\
\text { scientific researches will work and that will be supported by the } \\
\text { MTA budget. }\end{array}$ & 1 & 0 & 0,751 & 0,048 \\
\hline & $\begin{array}{l}\mathrm{STR}_{2} \text { : To make arrangements to ensure the periodic } \\
\text { appointment of worldwide foreign academicians who are } \\
\text { specialized in the field of geosciences in the MTA and to } \\
\text { provide appropriate environment in which they can work. }\end{array}$ & 2 & 0,286 & 0,813 & 0,057 \\
\hline & $\begin{array}{l}\text { STR }_{3} \text { : To give research topics to the graduate and doctoral } \\
\text { students who are studying in geosciences in Turkey and to } \\
\text { ensure that they can benefit from the technical facilities of } \\
\text { MTA. }\end{array}$ & 6 & 0,553 & 0,905 & 0,057 \\
\hline
\end{tabular}

From $S T R F_{m}$ formula, strategy feasibility ratio can be calculated as follows;

$$
\begin{array}{r}
S T R F_{m}=0,847=0,2 \times(0,2+0,18+0,22+0,25)+ \\
0,3 \times(0,2+0,22+0,22+0,22)+0,1 \times(0,13+ \\
0,13+0,2+0,25)+0,4 \times(0,23+0,14+0,25+0,25)
\end{array}
$$

Initial VIKOR model of ANP-VIKOR Hybrid Method is constructed with respect to matrix represented on Table 15 Baylan \& Erensal[2].

At the end of VIKOR calculations all strategy alternatives are sequenced according to increasing order of their Q values, because it satisfies the last step of VIKOR conditions. An example of strategy prioritization table is below which belongs to first strategic target. This strategic target has three different strategies. Strategy 1 that is underlined has the smallest $\mathrm{Q}$ value and that makes its priority and rank uppermost. That means Reaching the best way of "Conducting scientific studies to explain geological formations and events" strategic target is the strategy alternative "Within the MTA, to establish a scientific research center where researchers who can make professional academic level of scientific researches will work and that will be supported by the MTA budget". And strategy 2 and strategy 3 comes after that. In this method, it should be noted that priority values of strategies are found out as global values for strategic targets. That means strategies are not ranked by considering their own strategic targets. ANP-VIKOR method prioritize strategies by considering all strategic targets. Other prioritization tables are represented in Appendix.

\section{Results and Discussion}

In this study, ANP-VIKOR Strategy Prioritization method is applied to General Directorate of Mineral Research and Exploration's (2015-2019) strategic plan. ANP part of method is applied to original strategic plan information which are vision statement, SWOT analysis, strategic goals and strategic targets. In VIKOR model of method, original performance targets are assigned as decision criteria and strategies made up by experts are assumed as decision alternatives because whole real strategy alternatives are not included in strategic plan and also they are not very suitable to be broken down into projects. In application part, whole original strategic plan information is presented because some strategic information was very specific.

ANP-VIKOR Strategy prioritization method changes and improves traditional strategy prioritization process. During application study, effect of ANP-VIKOR Strategy

Prioritization Method on experts and decision process is observed. Followings are the results:

- Without applying any pressure on the strategic planning team, individuals were able to analyze the SWOT analysis factors, strategic targets and performance targets in an analytic manner through paired comparisons.

- The ANP-VIKOR hybrid method combines with a mathematical, the vision of the corporation of which a strategies plan is made, the SWOT analysis, strategic purposes, strategic targets, performance targets and strategy alternatives.

- The ANP-VIKOR hybrid method enables the strategic planning team to assess excessive SWOT analysis and strategy information in a short amount of time.

- The pairwise comparisons part of the method ensures that the strategic planning team eliminates the unimportant SWOT factors, strategic targets, strategic objectives and performance targets. That's because the pair comparisons use the 1-9 scale. This scale provides that very unimportant and inefficient factors are disclosed through comparison with other factors.

- The pairwise comparisons section of the method enables the members of the strategic planning team to make a mind exercise on the SWOT factors, strategic targets and performance targets before developing strategy alternatives. This analytic working phase enables the strategic planning team to produce more efficient strategy alternatives. 
- The pair comparisons section of the method enables the members of the strategic planning team to make a mind exercise on the SWOT factors, strategic targets and performance targets before developing strategy alternatives. This analytic working phase enables the strategic planning team to produce more efficient strategy alternatives.

- The fact that all strategic plan components are dynamically bound to each other via a mathematical model enables the strategic planning team to conduct a sensitivity analysis on the strategic plan components In other words, if the pairwise comparison values in the ANP-VIKOR model or if the strategy feasibility values in the VIKOR section are changed, such numerical changes can amend the priority sequences of the strategy. This enables the strategic planning team to test various ideas in the model.

- $\quad$ The ANP-VIKOR hybrid method provides a dynamic strategy control to the strategic planning team. If a strategy cannot manifest sufficient performance during a strategy planning period that was selected as the most efficient one for a particular strategic target (that's because the feasibility coefficient and yielded outputs of a strategy are previously estimated in percentage), the second most efficient strategy can be commissioned without losing time.

- At the end of the strategic planning period, the success of the strategies are measured by the extent, to which corporate targets could be reached. In a traditional strategic planning phase, no importance coefficient is assigned to performance targets through an analytic method. In the new ANP-VIKOR hybrid method however, the performance targets are distributed the importance coefficients of the strategic targets, which have been prioritized in the ANP model. This procedure enables the strategic planning team to measure the success of the strategies according to the weighted performance targets.

- Traditionally in strategic plans, the strategy alternatives are only selected through assessment according to the strategic targets that they are affiliated with (there are specific strategy alternative groups that are produced for reaching individual strategic targets). However, the VIKOR section of the new ANP-VIKOR hybrid method enables the strategy alternatives to be assessed according to all performance targets.

This proposed method may cause some difficulties while implementation process. Extracting expert opinions in a very systematic way may requires teaching some details of ANP-VIKOR Hybrid Strategy Rankings method. Namely, some strategy experts are required to know some mathematical and algorithmic concepts. Besides that some experts involved in strategic planning team might prefers simpler methods that are like brainstorming, cause-effect diagrams, and fishbone diagrams. In those cases, a short training program about that novel method should be carried out.

Strategy ranking decision method development is multidisciplinary subject. Therefore, this study has two improving directions. Especially, for government foundations strategic planning guide, it can be said that some structured SWOT analysis template, strategic goals and targets template could be modelled for some similar foundations like municipalities, government hospitals, and government universities. These templates increase the speed of strategic planning process and also provide ease to use ANP-VIKOR strategy prioritization method. Actually, these templates could be combined with this novel method and used professionally for those similar government foundations. Secondly, improving direction is dealing with uncertainties. Human judgments and strategy impacts may also be considered as uncertain. Both of them may be evaluated in fuzzy or stochastic environment. To increase the precision of pairwise comparisons, fuzzy-ANP method could be used and also fuzzy-VIKOR method could be used while forecasting strategies impacts on performance targets. On the other hand, future impacts of strategies on performance targets can be modelled stochastic. In literature, analytic strategy ranking methods do not involve evaluation future scenario alternatives. They only deal with current situation analysis. If they add future scenarios in the model, they can consider future performance of strategy alternatives while prioritizing them. 


\section{Appendix}

Table 13. Pairwise comparison factor of ANP part of decision method

\begin{tabular}{|c|c|}
\hline • & Pairwise comparisons for SWOT factors with respect to vision statement \\
\hline - & Pairwise comparisons for strategic goals with respect to vision statement \\
\hline • & Evaluation of SO factors with respect to elimination ability on weaknesses \\
\hline • & Evaluation of SO factors with respect to elimination ability on treats \\
\hline • & Evaluation of WT factors with respect to elimination ability on strengths \\
\hline • & Evaluation of WT factors with respect to elimination ability on opportunities \\
\hline - & Pairwise comparisons of sub-strengths with respect to strengths. \\
\hline • & Pairwise comparisons of sub-weaknesses with respect to weaknesses. \\
\hline • & Pairwise comparisons of sub-opportunities with respect to opportunities. \\
\hline • & Pairwise comparisons of sub-treats with respect to treats. \\
\hline • & Pairwise Comparison of Sub-Strengths with Respect to Each Sub-Weakness \\
\hline • & Pairwise Comparison of Sub-Opportunities with Respect to Each Sub-Weakness \\
\hline • & Pairwise Comparison of Sub-Strengths with Respect to Each Sub-Treat \\
\hline • & Pairwise Comparison of Sub-Strengths with Respect to Each Sub-Treat \\
\hline - & Pairwise Comparison of Strategic Goals with Respect to Each Sub-Weakness \\
\hline • & Pairwise Comparison of Strategic Goals with Respect to Each Sub-Treat \\
\hline • & Pairwise Comparison of Strategic Goals with Respect to Each Sub-Strength \\
\hline • & Pairwise Comparison of Strategic Goals with Respect to Each Sub-Opportunities \\
\hline • & Pairwise Comparison of Strategic Targets with Respect to Each Sub-Strength \\
\hline - & Pairwise Comparison of Strategic Targets with Respect to Each Sub-Opportunities \\
\hline - & Pairwise Comparison of Strategic Targets with Respect to Each Sub-Weaknesses \\
\hline • & Pairwise Comparison of Strategic Targets with Respect to each Sub-Treat \\
\hline • & Pairwise Comparison of Strategic Targets with Respect to each Strategic Goals \\
\hline
\end{tabular}

Table 14. Initial VIKOR Table of Strategy Ranking Model

\begin{tabular}{|c|c|c|c|c|}
\hline \multirow[b]{2}{*}{$\begin{array}{c}\text { Strategies } \\
\left(\mathrm{STR}_{\mathrm{i}}\right)\end{array}$} & \multicolumn{4}{|c|}{ Performance Targets $\left(\mathrm{PT}_{\mathrm{u}}\right)$} \\
\hline & $\mathrm{PT}_{1}$ & $\mathrm{PT}_{2}$ & $\ldots \ldots .$. & $\mathrm{PT}_{n}$ \\
\hline $\mathrm{STR}_{1}$ & $\mathrm{SP}_{11}$ & $\mathrm{SP}_{12}$ & $\ldots \ldots$. & $\mathrm{SP}_{2 \mathrm{n}}$ \\
\hline $\mathrm{STR}_{2}$ & $\mathrm{SP}_{21}$ & $\mathrm{SP}_{22}$ & ........ & $\mathrm{SP}_{3 \mathrm{n}}$ \\
\hline$\ldots \ldots$ & $\ldots \ldots$ & $\ldots \ldots$ & $\ldots \ldots$ & $\ldots \ldots$ \\
\hline$S T R_{m}$ & $\mathrm{SP}_{31}$ & $\mathrm{SP}_{32}$ & $\ldots \ldots .$. & $S P_{m n}$ \\
\hline$f_{x}^{*}$ & $f_{i}^{*}=\operatorname{Max} S P_{j 1}$ & $f_{1}^{*}=\operatorname{Max} S P_{j 2}$ & $\ldots \ldots$. & $f_{1}^{*}=\operatorname{Max} S P_{j 2}$ \\
\hline$f_{x}^{-}$ & $f_{1}^{-}=\operatorname{Min} S P_{j 1}$ & $f_{1}^{*}=\operatorname{Min} S P_{j 2}$ & ........ & $f_{i}^{*}=\operatorname{MinSP} P_{j 2}$ \\
\hline
\end{tabular}


Table 15. Normalized VIKOR Table

\begin{tabular}{|c|c|c|c|c|}
\hline \multirow[b]{2}{*}{$\begin{array}{c}\text { Strategies } \\
\text { (STR })\end{array}$} & \multicolumn{4}{|c|}{ Performance Targets (PTu) } \\
\hline & $\mathrm{PT}_{1}$ & $\mathrm{PT}_{2}$ & ........ & $\mathrm{PT}_{\mathrm{n}}$ \\
\hline $\mathrm{STR}_{1}$ & $\mathrm{NSP}_{11}=\frac{f_{1}^{*}-S P_{11}}{f_{1}^{*}-f_{1}^{-}}$ & $\mathrm{NSP}_{12}=\frac{f_{2}^{*}-S P_{12}}{f_{1}^{*}-f_{1}^{-}}$ & ........ & $\mathrm{NSP}_{1 n}=\frac{f_{n}^{*}-S P_{1 n}}{f_{n}^{*}-f_{n}^{-}}$ \\
\hline $\mathrm{STR}_{2}$ & $\mathrm{NSP}_{21}=\frac{f_{1}^{*}-S P_{21}}{f_{1}^{*}-f_{1}^{-}}$ & $\mathrm{NSP}_{22}=\frac{f_{2}^{*}-S P_{22}}{f_{2}^{*}-f_{2}^{-}}$ & ........ & $\mathrm{NSP}_{2 n}=\frac{f_{n}^{*}-S P_{2 n}}{f_{n}^{*}-f_{n}^{-}}$ \\
\hline$\ldots \ldots$. & $\ldots \ldots$ & $\ldots \ldots$ & $\ldots \ldots . .$. & $\ldots \ldots$ \\
\hline $\mathrm{STR}_{\mathrm{m}}$ & $\mathrm{NSP}_{m 1}=\frac{f_{1}^{*}-S P_{m 1}}{f_{1}^{*}-f_{1}^{-}}$ & $\mathrm{NSP}_{m 2}=\frac{f_{2}^{*}-S P_{m 2}}{f_{2}^{*}-f_{2}^{-}}$ & ........ & $\mathrm{NSP}_{m g}=\frac{f_{n}^{\dagger}-S P_{m n}}{f_{n}^{*}-f_{n}^{-}}$ \\
\hline
\end{tabular}

Table 16. Weighted Normalized VIKOR table of strategy ranking model

\begin{tabular}{|c|c|c|c|c|}
\hline \multirow[b]{2}{*}{$\begin{array}{c}\text { Strategies } \\
\text { (STRi) }\end{array}$} & \multicolumn{4}{|c|}{ Performance Targets ( $\mathrm{PT}_{\mathrm{u}}$ ) } \\
\hline & $\mathrm{PT}_{1}$ & $\mathrm{PT}_{2}$ & .. & $\mathrm{PT}_{\mathrm{n}}$ \\
\hline $\mathrm{STR}_{1}$ & $W \mathrm{NSP}_{11}=\mathrm{NSP}_{11} * W P T_{1}$ & $\mathrm{WNSP}_{12}=\mathrm{NSP}_{12} * W P T_{2}$ &.. & $\mathrm{WNSP}_{1 n}=\mathrm{NSP}_{1 n} * W P T_{n}$ \\
\hline $\mathrm{STR}_{2}$ & $\mathrm{WNSP}_{21}=\mathrm{NSP}_{21} * W P T_{1}$ & $\mathrm{WNSP}_{22}=\mathrm{NSP}_{22} * W P T_{2}$ &. & $\mathrm{WNSP}_{2 n}=\mathrm{NSP}_{2 n} * W P T_{n}$ \\
\hline$\cdots \cdots$ & ........ & ........ & .. & ........ \\
\hline STRm & $\mathrm{WNSP}_{m 1}=\mathrm{NSP}_{m 1} * W P T_{1}$ & $\mathrm{WNSP}_{m 2}=\mathrm{NSP}_{m 2} * W P T_{2}$ & .. & $\mathrm{WNSP}_{m n}=\mathrm{NSP}_{m n} * W P T_{n}$ \\
\hline
\end{tabular}

Table 17. $S, R$ and $Q$ calculations of VIKOR Table

\begin{tabular}{|c|c|c|c|}
\hline $\begin{array}{c}\text { Strategies } \\
\mathrm{STR}_{i}\end{array}$ & $S_{j}$ & $Q_{j}$ & $R_{j}$ \\
\hline $\mathrm{STR}_{1}$ & $S_{1}=\sum_{u}^{n} W N S P_{1 u}$ & $R_{1}=\max _{u}\left[W N S P_{1 u}\right]$ & $Q_{1}=\frac{v\left(S_{u}-S^{*}\right)}{\left(S^{-}-S^{*}\right)}+\frac{(1-v)\left(R_{u}-R^{*}\right)}{\left(R^{-}-R^{*}\right)}$ \\
\hline $\mathrm{STR}_{2}$ & $S_{2}=\sum_{u}^{n} W N S P_{2 u}$ & $R_{2}=\max _{u}\left[W N S P_{2 u}\right]$ & $Q_{2}=\frac{v\left(S_{u}-S^{*}\right)}{\left(S^{-}-S^{*}\right)}+\frac{(1-v)\left(R_{u}-R^{*}\right)}{\left(R^{-}-R^{*}\right)}$ \\
\hline$\ldots .$. & $\ldots .$. & $\ldots .$. & $\ldots .$. \\
\hline $\mathrm{STR}_{\mathrm{m}}$ & $S_{m}=\sum_{u}^{n} W N S P_{j u}$ & $R_{m}=\max _{u}\left[W N S P_{m u}\right]$ & $Q_{m}=\frac{v\left(S_{u}-S^{*}\right)}{\left(S^{-}-S^{*}\right)}+\frac{(1-v)\left(R_{u}-R^{*}\right)}{\left(R^{-}-R^{*}\right)}$ \\
\hline
\end{tabular}


Table 18. Priority, Q, S and R values of strategies at the end of ANP-VIKOR Strategy Prioritization Method

\begin{tabular}{|c|c|c|c|c|c|}
\hline Strategic Target & Strategy & $\begin{array}{l}\text { Priority } \\
\text { Value of } \\
\text { Strategy }\end{array}$ & $\begin{array}{c}\mathrm{Q} \\
\text { value }\end{array}$ & $\mathrm{S}$ value & $\mathrm{R}$ value \\
\hline \multirow{3}{*}{$\begin{array}{lc}\text { ST1: } & \text { Conducting } \\
\text { scientific } & \text { studies to } \\
\text { explain } & \text { geological } \\
\text { formations and events }\end{array}$} & $\begin{array}{l}\text { STR1: Within the MTA, to establish a scientific research } \\
\text { center where researchers who can make professional } \\
\text { academic level of scientific researches will work and that } \\
\text { will be supported by the MTA budget. }\end{array}$ & 1 & 0 & 0,751 & 0,048 \\
\hline & $\begin{array}{l}\text { STR2: To make arrangements to ensure the periodic } \\
\text { appointment of worldwide foreign academicians who are } \\
\text { specialized in the field of geosciences in the MTA and to } \\
\text { provide appropriate environment in which they can work. }\end{array}$ & 2 & 0,286 & 0,813 & 0,057 \\
\hline & $\begin{array}{l}\text { STR3: To give research topics to the graduate and doctoral } \\
\text { students who are studying in geosciences in Turkey and to } \\
\text { ensure that they can benefit from the technical facilities of } \\
\text { MTA. }\end{array}$ & 6 & 0,553 & 0,905 & 0,057 \\
\hline \multirow{3}{*}{$\begin{array}{l}\text { ST2: Conducting a } \\
\text { remote sensing study on a } \\
\text { scale of } 700.000 \mathrm{~km}^{2} \text { for } \\
\text { the purposes of mining, } \\
\text { geothermal, natural } \\
\text { disaster, environmental } \\
\text { pollution etc. using optic } \\
\text { sensors }\end{array}$} & $\begin{array}{l}\text { STR1: To realize the procurement of remote sensing work of } \\
700.000 \mathrm{~km}^{2} \text { by means of service procurement from } \\
\text { consulting firms in the field of GIS. }\end{array}$ & 28 & 0,783 & 0,93 & 0,072 \\
\hline & $\begin{array}{l}\text { STR2: Training of the people among the MTA staff who } \\
\text { will specialize in GIS and updating the GIS software. }\end{array}$ & 17 & 0,699 & 0,901 & 0,071 \\
\hline & $\begin{array}{l}\text { STR3: To make project calls by the MTA for the work of } \\
\text { remote sensing of } 700.000 \mathrm{~km}^{2} . \text { To support these project } \\
\text { financially. (The detection work of } 700.000 \mathrm{~m}^{2} \text { can be done } \\
\text { locally in a fragmented way.) }\end{array}$ & 37 & 0,836 & 0,936 & 0,075 \\
\hline \multirow{3}{*}{$\begin{array}{l}\text { ST3: Increasing the } \\
\text { studies to reduce the } \\
\text { damages due to natural } \\
\text { disasters arising from } \\
\text { geological events every } \\
\text { year by } 25 \%\end{array}$} & $\begin{array}{l}\text { STR1: To make information exchange with the organizations } \\
\text { and institutions engaged in earthquake and fault lines in the } \\
\text { world and to carry out joint researches on earthquake risks in } \\
\text { Turkey. }\end{array}$ & 11 & 0,634 & 0,914 & 0,062 \\
\hline & STR2: Updating the map of the fault lines in Turkey & 22 & 0,757 & 0,932 & 0,069 \\
\hline & $\begin{array}{l}\text { STR3: To make detailed researches on the location and } \\
\text { severity of the past earthquakes in Turkey geography and to } \\
\text { estimate the future earthquake risks. }\end{array}$ & 23 & 0,761 & 0,956 & 0,063 \\
\hline \multirow{3}{*}{$\begin{array}{l}\text { ST4: Determining the } \\
\text { protection and usage } \\
\text { methods of the caves and } \\
\text { karst ecosystems and } \\
\text { creating an inventory }\end{array}$} & $\begin{array}{l}\text { STR1: To provide financial and technical assistance to } \\
\text { the graduate and doctoral students who are studying in } \\
\text { the field of cave and karst ecosystem in Turkev to carry } \\
\text { out researches in the area of protection and use. }\end{array}$ & 14 & 0,688 & 0,923 & 0,0651 \\
\hline & $\begin{array}{l}\text { STR2: To get information and consultancy service on the } \\
\text { methods of protection and use from the organizations making } \\
\text { researches on caves and karsts in the world such as The } \\
\text { National Cave and Karst Research Institute. }\end{array}$ & 34 & 0,826 & 0,957 & 0,068 \\
\hline & $\begin{array}{l}\text { STR3: To determine the important cave and karst areas as a } \\
\text { pilot region in Turkey and to carry out experiments on the } \\
\text { issues of protection and use. }\end{array}$ & 41 & 0,859 & 0,966 & 0,069 \\
\hline \multirow{3}{*}{$\begin{array}{l}\text { ST5: Creating a } \\
\text { numerical geological } \\
\text { database in international } \\
\text { standards }\end{array}$} & $\begin{array}{l}\text { STR1: Hiring additional staff experienced in geographic } \\
\text { information systems for the creation of digital geology } \\
\text { database. }\end{array}$ & 19 & 0,744 & 0,905 & 0,075 \\
\hline & $\begin{array}{l}\text { STR2: Creating the digital geology database after training } \\
\text { the existing staff on the geographical information systems. }\end{array}$ & 24 & 0,762 & 0,911 & 0,075 \\
\hline & $\begin{array}{l}\text { STR3: To get consulting service on the geographical } \\
\text { information systems for faster creation of the database. }\end{array}$ & 36 & 0,832 & 0,905 & 0,075 \\
\hline \multirow{2}{*}{$\begin{array}{l}\text { ST6:Preparing and } \\
\text { printing geology maps for } \\
\text { different purposes and } \\
\text { with different scales. }\end{array}$} & $\begin{array}{l}\text { STR1: To prepare the geological maps of various purposes } \\
\text { and scales after analyzing the needs of the mining industry. }\end{array}$ & 31 & 0,808 & 0,937 & 0,072 \\
\hline & $\begin{array}{l}\text { STR2: To prepare the maps of various purposes and } \\
\text { scales by starting with the mines for which we have the } \\
\text { maximum data to create a map. }\end{array}$ & 27 & 0,788 & 0,931 & 0,072 \\
\hline \multirow{3}{*}{$\begin{array}{l}\text { ST7: } \\
\text { geological, geophysical, } \\
\text { hydrographical and } \\
\text { oceanographical } \\
\text { infrastructure } \\
\text { information for the } \\
\text { purpose of researching } \\
\text { the natural resources in } \\
\text { all our seas and } \\
\text { international waters with }\end{array}$} & $\begin{array}{l}\text { STR1: To provide financial and technical support to graduate } \\
\text { and doctoral students engaged in research in the field of } \\
\text { seabed geology in Turkey. }\end{array}$ & 8 & 0,563 & 0,907 & 0,058 \\
\hline & $\begin{array}{l}\text { STR2: To conduct joint research projects with countries with } \\
\text { the sea neighboring countries of Turkey. }\end{array}$ & 4 & 0,494 & 0,853 & 0,065 \\
\hline & $\begin{array}{l}\text { STR3: Recruiting new staff and receiving new technical } \\
\text { equipment in the MTA Marine and Environmental } \\
\text { Research Department. }\end{array}$ & 3 & 0,436 & 0,837 & 0,064 \\
\hline
\end{tabular}




\begin{tabular}{|c|c|c|c|c|c|}
\hline $\begin{array}{l}\text { Mediterranean sea as a } \\
\text { priority, natural } \\
\text { disasters, climate change, } \\
\text { protection and effective } \\
\text { usage of the coasts and } \\
\text { the environment }\end{array}$ & & & & & \\
\hline \multirow{3}{*}{$\begin{array}{l}\text { ST8: Conducting studies } \\
\text { for metallic mineral and } \\
\text { industrial raw material } \\
\text { explorations to and } \\
\text { contributing to the } \\
\text { finding of new sources }\end{array}$} & $\begin{array}{l}\text { STR1: Recruiting new staff specialized in metallic } \\
\text { minerals and industrial raw materials and receiving new } \\
\text { technical equipment for the Mineral Research and } \\
\text { Exploration Department. }\end{array}$ & 18 & 0,7 & 0,914 & 0,068 \\
\hline & $\begin{array}{l}\text { STR2: To make information exchange and to carry out joint } \\
\text { exploration projects with private mining companies. }\end{array}$ & 32 & 0,814 & 0,94 & 0,072 \\
\hline & $\begin{array}{l}\text { STR3: To conduct researches on the rare earth element in } \\
\text { Turkey. To support the research projects in this field. }\end{array}$ & 39 & 0,852 & 0,958 & 0,07 \\
\hline \multirow{3}{*}{$\begin{array}{lr}\text { ST9: } & \text { Gradually } \\
\text { increasing } & \text { the } \\
\text { exploration and } & \text { survey } \\
\text { studies regarding } & \text { energy } \\
\text { raw materials } & \end{array}$} & $\begin{array}{l}\text { STR1: Training the engineers working in the Energy } \\
\text { Raw Material Research and Exploration Department on } \\
\text { the cutting edge technology geophysical and geological } \\
\text { methods. }\end{array}$ & 9 & 0,616 & 0,886 & 0,068 \\
\hline & $\begin{array}{l}\text { STR2: Renovation of the equipment used in exploration of } \\
\text { energy raw materials. }\end{array}$ & 15 & 0,696 & 0,913 & 0,068 \\
\hline & $\begin{array}{l}\text { STR3: To cooperate with the energy companies in } \\
\text { exploration of energy raw materials. }\end{array}$ & 25 & 0,762 & 0,921 & 0,072 \\
\hline \multirow{3}{*}{$\begin{array}{l}\text { ST10: Creating and } \\
\text { updating the metallic } \\
\text { minerals, industrial raw } \\
\text { materials and geothermal } \\
\text { resources inventories }\end{array}$} & $\begin{array}{l}\text { STR1: Creating the inventory preparation units in all } \\
\text { regions of Turkey and emploving researcher engineers } \\
\text { here by the MTA. }\end{array}$ & 16 & 0,699 & 0,901 & 0,072 \\
\hline & $\begin{array}{l}\text { STR2: To allow the geology engineering departments and } \\
\text { research centers in all regions of Turkey for making the close } \\
\text { regions inventory preparation projects by providing them } \\
\text { financial and technical support. }\end{array}$ & 40 & 0,859 & 0,953 & 0,072 \\
\hline & $\begin{array}{l}\text { STR3: To reach the inventories in the hands of mining plants } \\
\text { processing the metallic minerals and industrial raw materials } \\
\text { in Turkey. }\end{array}$ & 44 & 0,886 & 0,963 & 0,072 \\
\hline \multirow{3}{*}{$\begin{array}{l}\text { ST11: By conducting } \\
\text { studies according to the } \\
\text { international standards } \\
\text { in search of minerals } \\
\text { energy raw materials, } \\
\text { contributing to the } \\
\text { enhancement of reserve } \\
\text { reliability }\end{array}$} & $\begin{array}{l}\text { STR1: Adaptation of the latest technology drilling data } \\
\text { evaluation program used in the mineral exploration and } \\
\text { reserve determination projects. }\end{array}$ & 12 & 0,668 & 0,911 & 0,066 \\
\hline & $\begin{array}{l}\text { STR2: To increase the capacity of the mineral analysis } \\
\text { laboratories within the MTA. Thus, the inventory } \\
\text { properties can be determined more accurately. }\end{array}$ & 10 & 0,621 & 0,888 & 0,068 \\
\hline & $\begin{array}{l}\text { STR3: Training of the related staff to comply with the } \\
\text { international resource-reserve reporting system. }\end{array}$ & 26 & 0,765 & 0,926 & 0,071 \\
\hline \multirow{3}{*}{$\begin{array}{l}\text { ST12: Ensuring the } \\
\text { continuation of } \\
\text { enhancing the capacities } \\
\text { of, diversifying and } \\
\text { expediting the } \\
\text { analysis/test quality } \\
\text { according to the } \\
\text { international standards }\end{array}$} & $\begin{array}{l}\text { STR1: To establish large testing analysis laboratories by } \\
\text { taking into account the situation of the mineral inventory in } \\
\text { Turkey. }\end{array}$ & 43 & 0,884 & 0,953 & 0,075 \\
\hline & $\begin{array}{l}\text { STR2: For performing the isotopic analysis successfully, to } \\
\text { train the laboratory staff in this regard. }\end{array}$ & 48 & 0,921 & 0,966 & 0,075 \\
\hline & $\begin{array}{l}\text { STR3: Due to the very rich reserves of marble in Turkey, to } \\
\text { train the laboratory staff in marble analysis and to receive the } \\
\text { latest technology marble analysis devices. }\end{array}$ & 53 & 0,947 & 0,975 & 0,075 \\
\hline \multirow{3}{*}{$\begin{array}{lr}\text { ST13: } & \text { Conducting } \\
\text { scientific } & \text { and } \\
\text { technological } & \text { studies, } \\
\text { producing } & \text { knowledge } \\
\text { and technology } & \end{array}$} & $\begin{array}{l}\text { STR1: To give incentive bonus for the academic } \\
\text { publications carried out within the MTA. }\end{array}$ & 13 & 0,681 & 0,696 & 0,071 \\
\hline & $\begin{array}{l}\text { STR2: To make arrangements for the academicians engaged } \\
\text { in researches in the field of mining and geology to be able to } \\
\text { use the MTA's technical facilities. }\end{array}$ & 21 & 0,752 & 0,929 & 0,069 \\
\hline & $\begin{array}{l}\text { TR3: To arrange a "Congress of Mineral Exploration and } \\
\text { Turkey Geology" every year in which the declarations on the } \\
\text { subjects of mineral exploration and the geology of Turkey are } \\
\text { presented. }\end{array}$ & 33 & 0,825 & 0,933 & 0,075 \\
\hline \multirow{2}{*}{$\begin{array}{l}\text { ST14: Increasing the } \\
\text { archiving capacity of the } \\
\text { core data bank }\end{array}$} & $\begin{array}{l}\text { STR1: To employ new staff for the unit responsible for the } \\
\text { drilling core archive. }\end{array}$ & 55 & 0,953 & 0,977 & 0,075 \\
\hline & $\begin{array}{l}\text { STR2: To make repair and maintenance planning of the } \\
\text { drilling equipment to improve the performance of core } \\
\text { sampling. }\end{array}$ & 42 & 0,886 & 0,968 & 0,069 \\
\hline \multirow{2}{*}{$\begin{array}{lr}\text { ST15: Raising natural } \\
\text { history awareness } & \text { by } \\
\text { concentrating } & \text { on } \\
\text { scientific, cultural and } \\
\text { social activities }\end{array}$} & $\begin{array}{l}\text { STR1: To publish a monthly natural history magazine to } \\
\text { be prepared in cooperation with the MTA. }\end{array}$ & 50 & 0,937 & 0,971 & 0,075 \\
\hline & $\begin{array}{l}\text { STR2: To make arrangements that will allow a group of } \\
\text { university student to visit the natural history museum each } \\
\text { week. }\end{array}$ & 52 & 0,944 & 0,974 & 0,075 \\
\hline
\end{tabular}




\begin{tabular}{|c|c|c|c|c|c|}
\hline & $\begin{array}{l}\text { STR3: To make a documentary of natural history in a } \\
\text { television channel to be prepared with the contribution of the } \\
\text { MTA. }\end{array}$ & 58 & 0,968 & 0,982 & 0,075 \\
\hline \multirow{3}{*}{$\begin{array}{lr}\text { ST16: } & \text { Performing } \\
\text { inventory works that } \\
\text { indicate our country's } \\
\text { geological } & \text { heritage } \\
\text { potential } & \end{array}$} & $\begin{array}{l}\text { STR1: To explore the potential availability of the known } \\
\text { geological heritage in Turkey for the purpose of } \\
\text { ecotourism. }\end{array}$ & 20 & 0,747 & 0,929 & 0,069 \\
\hline & $\begin{array}{l}\text { STR2: Comparing the formations accepted as the geological } \\
\text { heritage in the world with the geological heritage potential in } \\
\text { Turkey structurally. }\end{array}$ & 38 & 0,848 & 0,957 & 0,07 \\
\hline & $\begin{array}{l}\text { STR3: To employ staff specialized in geological heritage } \\
\text { within the MTA. }\end{array}$ & 30 & 0,795 & 0,741 & 0,07 \\
\hline \multirow{3}{*}{$\begin{array}{l}\text { ST17: Creating } \\
\text { individual and career } \\
\text { development } \\
\text { opportunities for the } \\
\text { employees and equipping } \\
\text { the newly recruited } \\
\text { personnel with the } \\
\text { necessary know-how to } \\
\text { assume responsibility in } \\
\text { the projects }\end{array}$} & $\begin{array}{l}\text { STR1: To encourage the in-house engineers at the MTA } \\
\text { to make postgraduate studies. }\end{array}$ & 29 & 0,793 & 0,921 & 0,075 \\
\hline & $\begin{array}{l}\text { STR2: To get service from consulting company for the } \\
\text { renewal of the orientation process applied to new staff. }\end{array}$ & 61 & 1 & 0,993 & 0,075 \\
\hline & $\begin{array}{l}\text { STR3: To organize seminars to allow the in-house experts at } \\
\text { the MTA to share their professional and technical knowledge }\end{array}$ & 56 & 0,951 & 0,977 & 0,075 \\
\hline \multirow{3}{*}{$\begin{array}{lr}\text { ST18: } & \text { Performing } \\
\text { promotional } & \text { and } \\
\text { publication activities }\end{array}$} & $\begin{array}{l}\text { STR1: Making arrangements to allow the MTA engineers to } \\
\text { publish articles describing the works of MTA in national and } \\
\text { international mining and geological magazines. }\end{array}$ & 60 & 0,978 & 0,985 & 0,075 \\
\hline & $\begin{array}{l}\text { STR2: To give success scholarship to the students having } \\
\text { training in earth sciences (mining, geology, geophysics } \\
\text { engineering) in Turkey. }\end{array}$ & 51 & 0,942 & 0,973 & 0,075 \\
\hline & $\begin{array}{l}\text { STR3: Make documentaries about the importance for the } \\
\text { mining industry in Turkey. }\end{array}$ & 54 & 0,95 & 0,976 & 0,075 \\
\hline \multirow{3}{*}{$\begin{array}{l}\text { ST19: Increasing } \\
\text { international } \\
\text { collaborations }\end{array}$} & $\begin{array}{l}\text { STR1: To carry out mineral exploration projects in the } \\
\text { international waters with the sea neighboring countries } \\
\text { of Turkey. }\end{array}$ & 5 & 0,498 & 0,432 & 0,071 \\
\hline & $\begin{array}{l}\text { STR2: To make projects for researching the fault line } \\
\text { structure of Turkey together with the world's leading } \\
\text { earthquake research centers. }\end{array}$ & 7 & 0,561 & 0,881 & 0,064 \\
\hline & $\begin{array}{l}\text { STR3: To make research projects with the international mine } \\
\text { exploration organizations in respect of exploration of rare } \\
\text { earth elements and reserve determination. }\end{array}$ & 35 & 0,832 & 0,945 & 0,072 \\
\hline \multirow{3}{*}{ 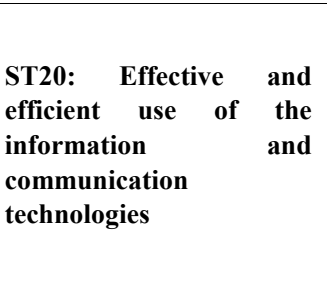 } & $\begin{array}{l}\text { STR1: To provide training to the MTA staff with the aim of } \\
\text { utilizing the information and communication technology } \\
\text { effectively. }\end{array}$ & 47 & 0,92 & 0,966 & 0,075 \\
\hline & $\begin{array}{l}\text { STR2: Renewal of the MTA's information system } \\
\text { infrastructure and designing an information system easier to } \\
\text { use. }\end{array}$ & 49 & 0,924 & 0,967 & 0,075 \\
\hline & $\begin{array}{l}\text { STR3: Recruiting computer engineer staff specialized in } \\
\text { information and communication technologies for MTA. }\end{array}$ & 46 & 0,918 & 0,965 & 0,075 \\
\hline \multirow{3}{*}{$\begin{array}{l}\text { ST21: Establishing a } \\
\text { Quality Management } \\
\text { System and Occupational } \\
\text { Health and Safety } \\
\text { Management System } \\
\text { within the institution and } \\
\text { adjusting the work } \\
\text { environment with the } \\
\text { compliance with } \\
\text { standards }\end{array}$} & $\begin{array}{l}\text { STR1: To establish the "Quality } \text { Management } \\
\text { Department" within the MTA. }\end{array}$ & 45 & 0,887 & 0,954 & 0,075 \\
\hline & $\begin{array}{l}\text { STR2: To get service from a company that provides quality } \\
\text { management consulting. }\end{array}$ & 57 & 0,967 & 0,982 & 0,075 \\
\hline & $\begin{array}{l}\text { STR3: To provide training for the MTA staff on the quality } \\
\text { awareness and occupational health and security. }\end{array}$ & 59 & 0,975 & 0,985 & 0,075 \\
\hline
\end{tabular}




\section{REFERENCES}

[1] Barney, D.N. Clark, (2008), Resource-based theory: creating and sustaining competitive advantage, (italics!) Oxford: Oxford University Press

[2] BAYLAN, E.B. \& ERENSAL, Y.C., (2016). Decision support method development via ANP combined VIKOR algorithm for strategy ranking of government agencies strategic planning template. Marmara University Institute of Applied Sciences.

[3] I Bonn, (2001), Developing strategic thinking as a core competency. Journal of Management Decision, 39(63-72).

[4] D.W. Brinkerhoff, (1994), Looking out, looking in, looking ahead. PA Times, 17(11).

[5] J. Carlsen, \& T.D. Andersson, (2011), Strategic SWOT analysis of public, private and not - for - profit festival organizations. International Journal of Event and Festival Management, 2(1), ss.83-97.

[6] A.D. Chandler, (1962), Strategy and structure: chapters in the history of the industrial enterprise. M.I.T. Press, Cambridge,

[7] G. Dessler Management, (2001) Principles and practices for tomorrow's leaders, 3.edition Pearson Prentice Hall, London

[8] A. Drejer, (2002), Strategic management and core competencies: Theory and application, Greenwood Press, Westport

[9] R.S. Kaplan, D.P. Norton, (2008), The execution premium: linking strategy to operations for competitive advantage, Harvard Business Press, Boston

[10] P. Kelly (2009) International business and management, Cengage Learning, London

[11] L.A. Leskinen, P. Leskinen, M. Kurttila, J. Kangas, M. Kajanus, (2006)Adapting modern strategic decision support tools in the participatory strategy process - a case study of a forest research station. Forest Policy and Economics Vol: 8, no:3, 267-278

[12] J.K. Pinto, (2009), Project management: international version: achieving competitive advantage, 2. edition, Pearson Education, Upper Saddle River

[13] M.E. Raynor, (2007), What is corporate strategy, really?. Ivey Business Journal Online. Vol: 71, no: 8, 1-6

[14] R. Robinson, The advantages and disadvantages of strategic management, (2005) https://charityvillage.com/Content.as px?topic $=$ the_advantages_and_disadvantages_of_strategic management $\#$.WMp0n4XXLIU $\overline{\text { I }}$. Accessed 19 February 2017.

[15] O. Shenkar, (2008), Y. Luo, International business. 2. edition Sage Publications, Thousand Oaks

[16] J. Kangas, M. Pesonen, M Kurttila, \& M. Kajanus, (2001) A'WOT: Integrating the AHP with SWOT Analysis, 6th ISAHP 2001 Berne, Switzerland, 189-198

[17] M. Kajanus, J. Kangas, \& M. Kurttila, (2004), The use of value focused thinking and the A'WOT hybrid method in tourism management, Tourism Management, Vol: 25, no:4, 499-506. http://doi.org/10.1016/S0261-5177(03)00120-1

[18] E. E. Osuna \& A. Aranda, (2007), Combining SWOT and AHP Techniques for Strategic Planning. Isahp, 1-8.

[19] I. Yüksel, \& M. Dağdeviren, (2007). Using the analytic network process (ANP) in a SWOT analysis - A case study for a textile firm. Information Sciences, 177(16), 3364 3382. http://doi.org/10.1016/j.ins.2007.01.001

[20] M. Ghorbani, R. Velayati, \& M. Ghorbani, (2011), Using Fuzzy TOPSIS to Determine Strategy Priorities by SWOT Analysis, Proceedings of the International ..., 11, 135-139.

[21] General Directorate of Mineral Research and Exploration Strategic Planning Team, (2015), General Directorate of Mineral Research and Exploration's (2015-2019) strategic plan, Ankara

[22] Özden, Ü.H., (2009), Türkiye' deki Mevcut Bankaların Performansları - Çok Kriterli Karar Verme Yöntemleri ile Analiz 1. edition, Ankara: Detay Publishing. 